УДК 811.581 .11

DOI https://doi.org/10.26661/2414-9594-2020-2-13

\title{
СТИЛІСТИЧНА КОДИФІКАЦІЯ: ПОЯВА ТА РОЗВИТОК ТРАДИЦЙНИХ ФОРМ ТЕКСТУ В МОВАХ ВЕНЬЯНЬ І БАЙХУА
}

\author{
Костанда I. O. \\ кандидат філологічних наук, \\ дочент кафедри китайської філологіі \\ Київський національний лінгвістичний університет \\ вул. Велика Васильківська, 73, Київ, Україна \\ orcid.org/0000-0002-5144-0941 \\ kostanda.iryna@ukr.net
}

\author{
Ключові слова: кодифікачія, \\ функиійні стилі, форми \\ тексту, види тексту, \\ стандартизаччія.
}

Одним із центральних понять при розгляді проблем формування та нормування мов $є$ поняття кодифікації, оскільки у процесі кодифікації досліджують і фіксують мовні норми, які уже потім розглядаються як іманентна властивість літературної мови. Система функційних стилів і стилістичних засобів їх вираження пронизує усі мовні рівні. 3 огляду на те, що літературній мові кожного народу у відповідні епохи властива своя власна система функційних стилів і стилістичних засобів, центром уваги нашої роботи $є$ кодифікація функційних стилів і стилістичних засобів їхнього вираження у китайських мовах веньянь і байхуа. Актуальність дослідження зумовлена необхідністю вивчення функційних стилів мов веньянь і байхуа, а також літератури зі стилістичної кодифікації давнього Китаю. Комплексний аналіз аспектів стилістичної кодифікації літератури давнього Китаю потрібен для того, щоб наочно проілюструвати відмінність та оригінальність стилів у мовах веньянь і байхуа, а також продемонструвати ідею наступності у формуванні означених вище мов. Розгляд функційних стилів, етапів їхнього формування та кодифікації допоможе показати важливість стилістичних аспектів для розвитку китайської мови та культури. Метою цієї наукової розвідки $\epsilon$ дослідження функційних стилів мов веньянь і байхуа та процесів стилістичної кодифікації давнього Китаю. У роботі було використано зіставний метод, описовий метод для класифікації та інтерпретації досліджуваних мовних явищ, історичний i порівняльно-історичний методи. Предметом дослідження є головні функційні стилі мов веньянь і байхуа. Об'єктом дослідження є процеси кодифікації та формування головних функційних стилів мов веньянь і байхуа. Історія стилістичної кодифікації, дослідження форм літератури та видів тексту в мовах веньянь і байхуа надає важливий матеріал для дослідження та пояснення лінгвістичних явищ сучасної китайської мови. Усебічний аналіз історії та концепції стилістичної кодифікації традиційних форм літератури та видів тексту може покласти початок новим науковим розвідкам у галузі стилістики та перекладознавства. 


\title{
STYLISTIC CODIFICATION: THE EMERGENCE AND DEVELOPMENT OF TRADITIONAL FORMS OF TEXT IN THE WENYAN AND BAIHUA LANGUAGES
}

\author{
Kostanda I. O. \\ Candidate of Philological Sciences, \\ Associate Professor at the Department of Chinese Philology \\ Kyiv National Linguistic University \\ Velyka Vasylkivska str., 73, Kyiv, Ukraine \\ orcid.org/0000-0002-5144-0941 \\ kostanda.iryna@ukr.net
}

Key words: codification, functional styles, text forms, text types, standardization.

\begin{abstract}
One of the central concepts in considering the problems of formation and standardization of languages is the concept of codification, as in the process of codification, language norms are studied and recorded, which are then considered as an immanent property of literary language. The system of functional styles and stylistic means of their expression of the system permeates all language levels. Since the literary language of each nation and each epoch has its own system of functional styles and stylistic means, in accordance with the above issues, the focus of our study is the codification of functional styles and stylistic means of their expression in Chinese Wenyan and Baihua. The relevance of the study is due to the need to study the functional styles of the Wenyang and Baihua languages, as well as the literature on the stylistic codification of ancient China. A comprehensive analysis of aspects of the stylistic codification of ancient Chinese literature is needed to clearly illustrate the difference and originality of styles in the Wenyang and Baihua languages, as well as to demonstrate the idea of continuity in the formation of the above languages. The purpose of this scientific exploration is to study the functional styles of the Wenyan and Baihua languages and the processes of stylistic codification of ancient China. The comparative method, descriptive method for classification and interpretation of the studied linguistic phenomena, historical and comparative historical methods were used in the work. The subject of the research is the main functional styles of the Wenyan and Baihua languages. The object of research is the processes of codification and formation of the main functional styles of the Wenyan and Baihua languages. The history of stylistic codification, the study of literary forms and types of text in the Wenyan and Baihua languages provides important material for the study and explanation of the linguistic phenomena of modern Chinese. A comprehensive analysis of the history and concept of stylistic codification of traditional forms of literature and types of text can give rise to new scientific explorations in the field of stylistics and translation studies.
\end{abstract}

Постановка проблеми. Одним із центральних понять при розгляді проблем формування та нормування мов є поняття кодифікації, оскільки у процесі кодифікації досліджуються та фіксуються мовні норми, які уже потім розглядаються як іманентна властивість літературної мови. Коли система мови починає функціонувати, породжуючи різні стилі мови, починають діяти стилістичні норми. Стилістично відповідне використання мови регулюється стилістичними нормами, знання яких необхідне для успішної комунікації. Система функційних стилів і стилістичних засобів їхнього вираження пронизує усі мовні рівні: синтаксичний рівень, який включає у себе всі можливі способи комбінації знаків один 3 одним; семантичний рівень, котрий враховує співвідношення між тим, що означає, й означуваним, і прагматичний рівень, який включає в себе можливі варіації та контексти вживання мови.

Оскільки літературній мові кожного народу та кожної епохи властива своя система функційних стилів і стилістичних засобів, то відповідно до зазначеної вище проблематики центром уваги нашого дослідження $\epsilon$ кодифікація функційних стилів і стилістичних засобів їхнього вираження у китайських мовах веньянь і байхуа. 
Водночас у вітчизняних лінгвістичних розвідках досі відсутній опис функційних стилів, стилістичних норм веньянь і байхуа та носіїв стилістичної кодифікації означених вище мов.

Огляд літератури. Дослідженнями особливостей китайської стилістики займалися (здебільшого на прикладі художньої літератури) B.I. Горєлов, М.В. Крюков, С.P. Кучера, I.C. Лисевич, Л.Н. Меньшиков, Л.С. Переломова, Є.Б. Поршнева, Б.Л. Ріфтін, М.Е. Срмаков, А.І. Кобзєв, В.В. Малявін, Г.А. Ткаченко, С.А. Торчинова.

Вивченням китайської лексикографічної традиції займалися Н.Ф. Алефіренко, А,Н. Баранов, Л.А. Введенська, В.І. Горєлов, В.А. Звегінцев, В.С. Кім, Б.Г. Фаткулін, Х. Касарес, В.А. Козирєв, В.Д. Черняк, В. Соколов, М.В. Софронов, P.М. Цейтлін та ін., однак досліджень, присвячених процесам кодифікації стилістики мов веньянь i байхуа, нами не було помічено,

Актуальність статті зумовлена необхідністю вивчення функційних стилів мов веньянь і байхуа, а також літератури зі стилістичної кодифікації давнього Китаю. Комплексний аналіз аспектів стилістичної кодифікації літератури давнього Китаю дозволить наочно проілюструвати відмінність та оригінальність стилів у мовах веньянь і байхуа, а також показати ідею наступності у формуванні означених вище мов. Також розгляд функційних стилів, етапів їх формування та кодифікації допоможе показати важливість стилістичних аспектів для розвитку китайської мови та культури. 3 огляду на відсутність подібних наукових розвідок у вітчизняному мовознавстві виникає необхідність проведення подібного дослідження.

Метою цієї наукової розвідки $є$ вивчення функційних стилів мов веньянь і байхуа та процесів стилістичної кодифікації давнього Китаю. Мета роботи досягається через розв'язання таких завдань:

- розгляду літератури, яка $є$ носієм стилістичної кодифікації;

- дослідження історії розвитку форм і видів тексту мовами веньянь і байхуа;

- аналізу особливостей стилістичної кодифікації форм тексту.

Методи. У роботі було використано зіставний метод, описовий метод для класифікації та інтерпретації досліджуваних мовних явищ, історичний і порівняльно-історичний методи.

Предметом дослідження $є$ головні функційні стилі мов веньянь і байхуа. Об'єктом - процеси кодифікації та формування головних функційних стилів мов веньянь і байхуа.

Перша спроба кодифікації текстів за формою та стилем кодифікації мови веньянь була зроблена за періоду Трицарства (三国, 221-280рр.) у філологічній праці Цао Пі (曹不) «Дянь лунь. Лунь вень» (《典论. 论文», досл. «Обговорення класики. Критичні статті») [1, с. 50]. У цьому дослідженні не йдеться про визначення та класифікацію функційних стилів, але уже можна побачити спробу систематизації мовного матеріалу за видами та функціями.

В означеній вище праці автор визначив чотири види текстів [1, с. 54]: «меморандум» (奏议), «обговорення літератури» (书论), «вшанування пам'яті померлої людини» (铭俫), «прості вірші й оди» (诗赋), однак зауважимо, що ця класифікація мала великий недолік: не вся відома на той період література підходила під таку класифікацію, тож значна кількість творів лишилася не задіяною. За часів Західної династії Цзінь (西晋, 265-420рр.) виходить праця Лу Цзі (陆机) під назвою «Вень Фу» (《文赋», досл. «Проза та вірші») [1, с. 89], у якій вже було визначено десять видів тексту й описано стилістичні ознаки кожного.

За періоду правління Південної династії Ляо (南朝梁, 97-125 pp.) спадкоємець трону Чжаомін (昭明太子) написав дослідження зі стилістики під назвою «Вень сюн» (《文选», досл. «Обрані твори»), ця робота увійшла в історію китайської філології під назвою «Чжаомін вень сюн» («昭 明文选》, досл. «Обрані твори Чжаоміна») [2; 3]. Ïї особливістю було авторське рішення не обирати для розгляду такі форми тексту, які мали свою сталу сформовану форму організації мовного матеріалу:

- канони (经书);

- філософські теорії (诸子);

- літописи (史书).

Тоді письмові твори розподіляти на два види «вень» (《文》) i «пи» (《笔》). 《Пи »- це письмові твори, написані «без літературного таланту» («没 有文采的文章》) [3], здебільшого це стосувалося таких форм тексту, як документація, різні обліки тощо. «Вень» - це твори, написані «з літературним талантом» (《有文采的文章》) [1, с. 58]. Тож саме твори «вень» Чжаомін обрав для свого дослідження та поділив їх на 38 видів за формою.

За Південних і Північних династій, а саме за часів правління південної династії Ці (南朝 齐, 479-502 рр.) виходить видатна праця теоретика китайської філології Лю $\mathrm{Ce}$ (刘劦思, 465-521 рр.) «Вень Сінь Діао Лун» (《文心雕龙》, досл. «Літературний дух різьбленого дракона») [3]. У зазначеному дослідженні розглядалися форми та стилістичні засоби конфуціанських канонів, філософських творів, літописів, віршованої літератури та ін.

«Вень Сінь Діао Лун» і «Чжаомін вень сюн» стали взірцевими творами у сфері стилістики, які упродовж століть брали за основу багато поколінь китайських лінгвістів. Також зазначимо, що ці дослідження кодифікували стилістичні 
норми та запустили процеси нормування стилістики веньяня.

Значним кроком в історичному процесі стилістичної кодифікації була поява двох праць у часи правління династії Мін (明朝, 1368-1644рр.) [1, с. 135]:

- праця «Критичний аналіз форм статей» (《文章辨体》) за авторства У Не (吴讷), у якій розглянуто 59 форм тексту;

- праця «Чіткий аналіз форм статей» («文体 明辨》) за авторства Сю Шицена (徐师曾), у якій розглянуто 127 форм тексту.

За часів правління династії Цін (清朝, 1644-1911 рр.) вийшла праця (姚䩈编) під назвою «Гу вень ци лей цуань» (《古文辞类纂》, досл. «Компіляція стилістичних форм стародавнього тексту») автора Яо Ная (姚鼎), у якій визначено 13 стилістичних форм тексту, такі як: «теорія та критика» (论辨), «передмова та післямова» (序跋), «меморандум» (奏议), «обговорення літератури» (书说), «вступне слово до подарунка» (赠序), 《едикт» (诏令), «життєпис» (传状), «написи на кам’яних стелах» (碑志), «примітки про різне» (杂记), «римовані написи та повчальні написи»(筬铭), «вихваляння» (颂赞), «пісні й оди» (辞赋), «панегірик» (哀祭) [4, с. 153]. Ця робота стає своєрідним підсумком кодифікаційних процесів стилістики веньяню.

Усі вищеозначені роботи не охоплюють значну частину функційних стилів китайської мови. Причиною цього $є$ розподіл літератури на «низьку» та «високу» [4, с. 93]. Форми текстів «високої» літератури, які ми розглянули вище, через кодифікацію ставали стилістичною нормою. Стилі та стильові засоби «низької» літератури кодифікувати та стандартизувати не вважали за потрібне, тому класифікації форм тексту «низької» літератури почали з'являтися лише на початку XX ст., й обмежений обсяг нашої роботи не дозволяє навести всі дослідження, присвячені формам тексту та класифікації функційних стилів і форм їхньої реалізації. Саме тому ми розглянемо класичну модель класифікації стилів і форм тексту мов веньянь і байхуа.

Для класифікації функційних стилів і видів тексту, у яких вони реалізуються, ми повинні враховувати культурну специфіку й історичне тло формування різних видів тексту, а також сферу застосування цих текстів. Беручи це до уваги, у мовах веньянь і байхуа можна виділити шість форм літератури, такі як:

1) Стародавня проза (古文) - це неримована проза без вживання паралелізму. Ії функційний стиль можна схарактеризувати як проміжний між публіцистичним і художнім, він реалізується в таких видах тексту: «канонах» (经, повна назва: 书经), «літописах» (史, повна назва史书), «філософських теоріях» (子, повна назва: 诸子) [5, с. 158].
2) Римована проза (韵文) - це вірші та віршована проза, функційний стиль якої можна схарактеризувати як художній. Він реалізується у таких видах тексту: віршах вільної форми (自由体诗); віршах уставної форми або метричній поезії (格 律诗); віршованій прозі таких видів, як «римовані написи та повчальні написи» (筬铭), «вихваляння» (颂赞), «написи на кам’яних стелах» (碑志), «панегірик» (哀祭); «римований текст для навчання (грамоті) у вигляді народних пісень» (通俗歌诀) [4].

3) Паралельна проза (骈文) - це різновид тексту, побудований на основі паралельних конструкцій. Головною особливістю такого виду тексту $є$ контрастність або протиставлення, що відображається у трьох аспектах. По-перше, у структурі речень: речення у всьому тексті поєднані між собою однаковою граматичною побудовою, симетричні ієрогліфи кожного речення (усі перші, другі, треті четверті і т. д. ієрогліфи тексту) $є$ синонімами або антонімами [5, с. 264]. Найбільш популярна метрична форма такого тексту - це речення 34 або 6 ієрогліфів. По-друге, з погляду фонології у реченнях $\epsilon$ чергування тонів (平 大相反), наприклад, перший ієрогліф першого речення має «рівний тон» (平), тож перший ієрогліф другого речення повинен мати «нерівний тон» (穴) [5, с. 268].

Функційний стиль можна схарактеризувати як проміжний між публіцистичним та офіційно-діловим, він реалізується в таких видах тексту, як: «теорія та критика» (论辨), «передмова та післямова» (序跋), «меморандум» (奏议), «обговорення літератури» (书说), «вступне слово до подарунка» (赠序), «едикт» (诏令), «життєпис» (传状) та ін. Наприклад, усі форми текстів, описані Лю Се (刘妿思) у «Вень Сінь Діао Лун» (《文心雕龙》), належать до паралельної прози. Види текстів паралельної прози можна розподілити за тематикою [3; 1 , с. 386]:

- форми тексту, які мають за мету висловити ліричні почуття або критичне ставлення [4, с. 248]: «теорія та критика» (论辨), «передмова та післямова» (序跋), «меморандум» (奏议), «обговорення літератури» (书说), «вступне слово до подарунка» (赠序), 《едикт» (诏令);

- форми тексту, що мають на меті надати опис iз поясненнями супутніх обставин: «життєпис» (传状), 《примітки про різне» (杂记) та ін.

4) Римована та неримована проза мішаної форми (韵散夹杂) - це форма тексту, для якої характерне чергування використання прози та віршів. Розвиток «мішаної форми» починається із практики перекладу буддійських текстів [5, с. 197]. Функційний стиль можна схарактеризувати як художній, він реалізується в таких видах тексту, як «бяньвен» (变文). Ранні «бянвені» проповідували історії та ідеї буддизму, а пізні - передавали легенди, історичні події, що зберігалися у фольклорі [5, с. 198]. «Мішана форма» тексту дала поштовх для розвитку такої форми, як драма. 
5) Драма (戏曲) - це форма тексту, призначеного для виконання на сцені. Ïї функційний стиль можна визначити як художній, реалізація стилю відбувається у таких видах тексту: арії «曲》 (поетичному тексті); «монолозі» (说白), «діалозі» (对话), «клині» (《楔子») [5, с. 147]. Щоб характеристика драми як окремої форми тексту у мові байхуа була цілісною, слід зазначити, що всі означені вище форми тексту драми є закінченим текстом, зі своїми законами побудови та завершеною думкою. Ця особливість демонструє відмінність традиційних китайських драматичних творів від західноєвропейських, де цілий драматичний твір є «текстом-монолітом», а не «розпадається» на окремі тексти зі своїми законами побудови та закінченою думкою.

6) Оповідання (小说) - це форма тексту, функційний стиль якого можна визначити як художній. Одразу слід зазначити, що більш звичний переклад 小说 - «роман», однак це слово має кілька шарів змісту, і первісне значення можна описати як «текст, поданий у формі оповідання». «Оповідання» реалізується у таких формах [5, с. 174]:

- у мові веньянь це «нотатки про дивовижне» (志怪), цю форму можна схарактеризувати як коротку нотатку й «описи надзвичайного» (传奇) i визначити як оповідання;

- у мові байхуа це форми «історія, яка передається в усній формі» (话本), розширене оповідання, новела та «роман» (小说).

Висновки й перспективи подальших наукових досліджень у цьому напрямі. Розгляд історії стилістичної кодифікації та стандартизації видів тексту мовами веньянь і байхуа дозволяє зробити такі висновки:

1. Стилістична класифікація традиційних форм літератури та видів тексту розкриває націо- нальну специфіку, закладену у поняттях «література» $\mathrm{i}$ «текст» у мовах веньянь і байхуа.

2. Упродовж усієї історії китайської філологічної традиції кодифікувалися лише стилістичні форми та види текстів мови веньянь, форми текстів мовою байхуа не систематизувалися та не досліджувалися через етико-соціальні причини. Концепція кодифікації форм тексту лише «високої» літератури не змінювалася до кінця XIX ст.

3. Переважна більшість традиційних форм тексту мовою веньянь завдяки кодифікації продовжувала своє існування в автентичному вигляді впродовж століть. Наприклад форма тексту 奏议 «меморандум» уперше трапляється у філологічній праці Цао Пі «Дянь лунь. Лунь вень», і надалі ми можемо простежити опис цього виду тексту у всіх значних працях зі стилістики, включно 3 дослідженням «Гу вень ци лей цуань» Яо Ная, проведеним за правління династії Цін.

4. Велика увага у процесах стилістичної кодифікації приділяється дослідженню й опису віршованих видів тексту, такі тексти наявні у всіх формах літератури упродовж усього історичного розвитку стилістичної кодифікації. Віршовані види тексту - це фактично єдині носії художнього стилю, які кодифікували та зберігали у дослідницькій літературі.

Історія стилістичної кодифікації, дослідження форм літератури та видів тексту в мовах веньянь $\mathrm{i}$ байхуа надає важливий матеріал для дослідження та пояснення лінгвістичних явищ сучасної китайської мови. Всебічний аналіз історії та концепції стилістичної кодифікації традиційних форм літератури та видів тексту може покласти початок новим науковим розвідкам у галузі стилістики та перекладознавства.

\section{ЛITEPATУРA}

1. 周秉钓. 古汉语自学手册. 湖南 : 湖南任命出版社, 1955. $522 \mathrm{c}$.

2. 李南晖. 中国古代文体学论著集目 (1900-2014). 北京 : 北京大学出版社, 2016. 504 c.

3. 周振华. 《文心雕龙》与《昭明文选》中俫文的选文比较, 2020. URL: https://wenku.baidu.com/view/ c2d1ca1bff0a79563c1ec5da50e2524de518d0e3.html\#.

4. 姚舅. 古文辞类纂. 上海 : 上海古籍出版社, $1998.799 \mathrm{c}$.

5. 郭英德. 中国古代文体学论稿. 北京 : 北京大学出版社, 1995. $224 \mathrm{c}$.

\section{REFERENCES}

1. Zhou Bingdiao (1955) Gu hanyu zixue shouce. [Ancient Chinese Self-study] Hunan : Hunan renming chuben she [in Chinese]

2. Li Nanhui (2016) Zhongguo gudai wenti xue lunzhu ji mu (1900-2014) [Collection of Works on Ancient Chinese Stylistics (1900-2014)] Beijing : Peking University Press [in Chinese]

3. Zhou Zhenhua (2020) "Wen xin diao long" yu "Zhaoming wenxuan" zhong li wen de xuan wen bijiao. [Comparison of the selected essays in "Wenxindiaolong" and "Selected Works of Zhaoming"] URL: https://wenku.baidu.com/ view/c2d1calbff0a79563c1ec5da50e2524de518d0e3.html\# [in Chinese]

4. Yao Nai (1998) Guwen ci lei zuan. [Lexicographical compilation of ancient Chinese] Shanghai: Shanghai Ancient Books Publishing House [in Chinese]

5. Guo Yingde (1995) Zhongguo gudai wenti xue lun gao [Chinese Ancient Stylistics] Beijing : Peking University Press [in Chinese]. 